\title{
Asset Integrity Knowledge Management: A Case Study from the Petroleum Industry
}

\author{
Mayang Kusumawardhani \\ University of Stavanger, Stavanger and and Trancergy AS, Norway \\ Email: mayang.kusumawardhani@uis.no (Corresponding Author)
}

\author{
Tore Markeset \\ University of Stavanger, Stavanger, Norway \\ Email: tore.markeset@uis.no
}

\begin{abstract}
The practice of knowledge management in the petroleum industry is motivated by the HSE, technical and business requirements. Aligned with the development of knowledge management, various advancements in information systems are used to maintain the asset integrity of petroleum installations. However, the advancement also poses its own risks. With the increasing use of advanced technology in the petroleum installations, there are potential threats that can affect the installation's integrity. This paper aims to identify knowledge management and information system practices and challenges in maintaining the asset integrity of petroleum installations. This study is part of a larger-scale case study that analyzes current asset integrity management (AIM) practices in the petroleum industry. The study is based on a literature study and face-to-face interviews with industry practitioners in Houston, Texas, and Singapore. The main findings revealed seven groups of AIM challenges; knowledge management and information technology are part of these.
\end{abstract}

Keywords: information technology, information system, industrial services, knowledge management, asset integrity, asset management.

\section{INTRODUCTION}

The applications of information system (IS) in organization's knowledge management (KM) have been expanding alongside advancements in information and communication technology (ICT), such as digital technology (Brynjolfsson, 2012). Digital technology processes data in order to deliver necessary information to the intended recipient. The management of knowledge enables appropriate information to be obtainable whenever it is required in order to support decision-making. Various advancements in IS technologies are also applied in asset integrity management (AIM) of petroleum installations. Moreover, KM and IS are present in the entire life cycle of a petroleum installation. For example, facility operators have utilized data to support asset integrity applications, such as in decision-making tools, performance monitoring and improvement tools in various life cycle phases (see for example Brule, 2013, Gang et al., 2010, Karim et al., 2009).
However, with the increasing use of digital technology and advances in IS, there are potential threats that can affect the installation's integrity (Brynjolfsson, 2012, Ringstad and Andersen, 2006, Torstensen and Skramstad, 2008). Although information technology has brought petroleum activities into a new horizon, the adaptation of new technologies is not without its challenges. For example, companies are not able to avoid the development of technology in order to compete and adhere with government regulatory (Kusumawardhani and Markeset, 2014). Besides that, challenges also arise from other aspects of KM that are related to the characteristics of the installation itself, such as environment and geographical aspects. These potential issues can be identified in a systematic manner, by associating the related components in KM and IS with the installation's integrity factors. Once these challenges are identified, the organization will be able to establish the necessary prevention and mitigation procedures in managing the asset integrity.

\subsection{Definitions}

Knowledge management typically involves the handling of data, which is backed-up by the information system (IS). IS is a system that accepts data resources as input and processes them into information products as output. The handling of data includes various activities necessary to process data into information and then to manage the information until it reaches the end-users. Data handling consists of data-related activities such as data input, data processing, output, storage, feedback and control. Related KM activities are enabled by the use of technology, especially ICT; however, the involvement of the human factor is also a necessity. The advancement in technology allows increasing functions of $\mathrm{KM}$ such as operations support, management support, and decision-making support. With the growing demand for KM functions, components of $\mathrm{KM}$ are expanding from data, humans, procedures, and simpler technology such as software and hardware to include more developed technology such as telecommunication and network (Marakas and O'brien, 2013). These components interact and integrate to form a collective entity (i.e. system) in order to serve its function as illustrated in Figure 1. The feedback loop and control is 
inevitably present to adjust system performance to fulfill its function output.

From the discussion, we can form a definition of KM that fits with the context of this paper: "knowledge management is an organized planning, coordination and control of organizational activities and resources to effectively capture, distribute, and use knowledge." IS, however, is a part of KM that is defined as "any organized combinations of information and communication technology (ICT) and human's activities that utilizes the ICT to ensure handling of data in order to serve its objectives in an organization".

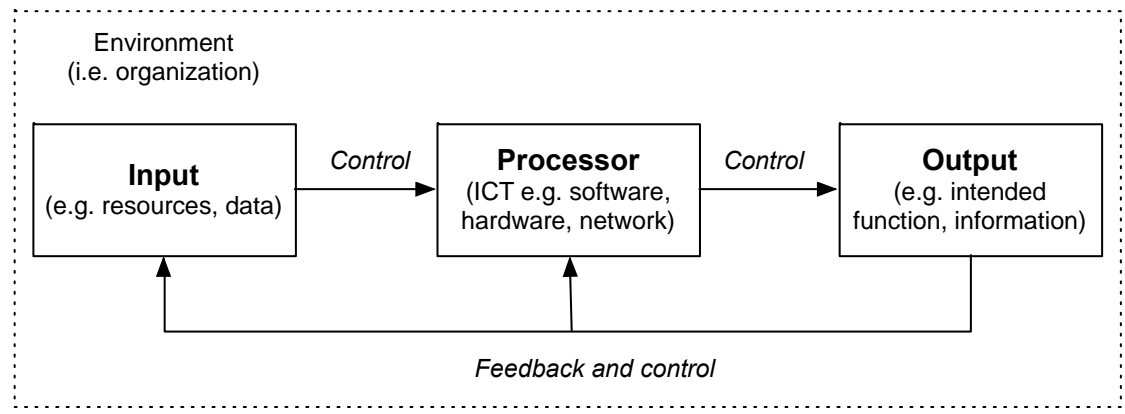

Figure 1. Basic information system process

\subsection{Knowledge management for Asset Integrity Management}

Besides the previously discussed fundamental components, the application of $\mathrm{KM}$ in a petroleum installation involves more complex processes and dynamic socio-technical environments. For an offshore installation, the socio-technical environment includes onshore and offshore working environments as illustrated in Figure 2.

Figure 2 illustrates a simple KM process in the operation phase of a petroleum installation. As well as in the operation phase, $\mathrm{KM}$ is also present in the entire lifecycle.

These systems are interdependent on one another, since they carry the facility's data. Prior to the operation phase of a facility, several types of data need to be made available, such as provision of technical system evaluation, equipment identification and specifications, equipment classification and other required information. The data gathered from this process is integrated into the database system intended for maintaining asset integrity.

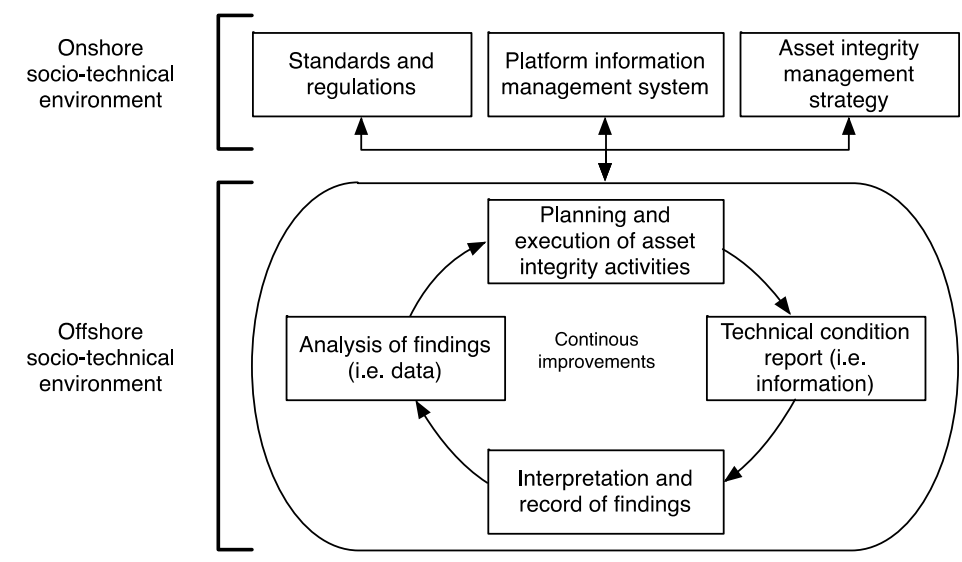

Figure 2. Example of asset integrity KM for an offshore installation

The data gathered then integrates with real-time data taken from sensors installed in the equipment or system in the operation phase. In the operation phase, the data is being used for maintenance analysis. Nowadays, the maintenance operating system has become proactive and capable of analysis functions, such as prognostic maintenance, diagnostic maintenance and forensic maintenance. The analysis system is able to monitor and diagnose the current system performance from the real-time data. The operating system also acquires forensic data from prior failures in order to give a prognosis of the health of the equipment, and it can predict future system performance. Besides basic maintenance functionality, the provision of adequate information on the equipment can be used as decision support and to improve equipment performance. Table 1 summarizes the maintenance analysis enabled by utilizing equipment data. 
Table 1. Maintenance analysis from equipment data

\begin{tabular}{|c|c|c|c|}
\hline \multirow{2}{*}{ Criteria } & \multicolumn{3}{|c|}{ Analysis types } \\
\hline & Diagnostic & Prognostic & Forensic \\
\hline Occurrences & Real-time diagnostic & Prior to failure/prognosis & Posterior to failure \\
\hline $\begin{array}{l}\text { Performance } \\
\text { analysis }\end{array}$ & $\begin{array}{l}\text { Current performance monitoring: to } \\
\text { monitor the performance and the } \\
\text { health of the system using real-time } \\
\text { information }\end{array}$ & $\begin{array}{l}\text { Future performance prognosis: to } \\
\text { estimate the degradation rate and } \\
\text { predict future performance }\end{array}$ & $\begin{array}{l}\text { Fault investigation: to investigate } \\
\text { situations after the fact, and to } \\
\text { establish what occurred based on } \\
\text { collected evidence }\end{array}$ \\
\hline Failure analysis & $\begin{array}{l}\text { Failure detection: to indicate whether } \\
\text { something is going wrong in the } \\
\text { current monitored system }\end{array}$ & $\begin{array}{l}\text { Failure prediction: to determine whether } \\
\text { a fault is impending and estimate how } \\
\text { soon and how likely a fault will occur }\end{array}$ & $\begin{array}{l}\text { Fault identification: to identify the } \\
\text { nature of the fault when it is detected }\end{array}$ \\
\hline
\end{tabular}

Today, the significance of real-time data and informed decision-making is highly regarded. Therefore, technological development focuses on delivering seamless information from plant facility to the intended users and vice versa. The real-time data is produced by various instruments mounted on equipment, while other sources of data might come from industrial experience, manufacturer's data, historical data, etc.

The term 'smart technology' relates to the ability of a system to process real-time data. The real-time data is analyzed in order to observe, predict and proactively interact with the monitored system. Furthermore, the data can also be utilized and integrated with other sets of information to be developed using analytical systems and other data processing to help transform data into a meaningful presentation to support decision-making. For example, in the case of equipment performance monitoring, correct information has helped the organization to make better maintenance decisions on equipment before it fails (Fidler, 2009).

\section{KNOWLEDGE MANAGEMENT CHALLENGES}

A research study was conducted to analyze the practices and challenges of AIM in offshore installations. A part of the study analyzes the role that knowledge management plays in maintaining the asset integrity. The data for the case study were gathered from multiple data collection methods and sources, mainly from interviews and information provided by respondents. Industrial practitioners located in Houston, Texas, USA, and Singapore participated in semi-structured face-to-face guided interviews. The KM related questions were constructed to investigate $\mathrm{KM}$ practices in managing asset integrity, concerns and other implementation variables within the organizations.

\subsection{The Case Study}

Respondents were divided into two groups: one group consisting of respondents from operator or installation owner (OP) organizations and the second group consisting of respondents from service providers or manufacturing companies (SP), as illustrated in Figure 3. In total, there were 15 respondents, eight located in Houston and seven in Singapore. The data gathered from interviews (data set A) were analyzed together with findings from the case study and literature study (data set B).

\subsection{Findings and Discussions}

In the interviews, respondents were asked about their organization's practice and concerns in KM with regard to the asset integrity of offshore installations. From data set A, respondents expressed the following concerns in relation to KM:

- Knowledge transfer

- Information management

- Data transfer between onshore and offshore

Other concerns that were gathered from data set B are:

- Information technology (IT) processes and security

- Quality of data

- Integrated system

- Introducing and adapting to new technology

From data set A, it was apparent that respondents' preferences towards KM depended on their short-term and long-term strategies. Respondents were aware of the cost of establishing KM, but they also considered the trade off between short-term and long-term benefits. The findings from both data sets are discussed below.

\section{- Knowledge transfer}

Some of the respondents reported experiencing challenges in acquiring documentation and records, either from the previous owner/operator or from the present operation and maintenance $(\mathrm{O} \& \mathrm{M})$ activities. Management of knowledge is crucial and needs to be established early in the facility's life cycle; however, engaging sophisticated software is not the final answer. Most of the respondents are utilising state-of-the-art document management systems and CMMS, but the tools are only as good as the input.

Some of the challenges were an easy fix; for example, if an organization does not have guidelines for document management, then the organization needs to establish suitable procedures. This is also related to the tag management of the asset, where it was discovered that some organizations do not develop a pipeline list or a proper equipment register. 


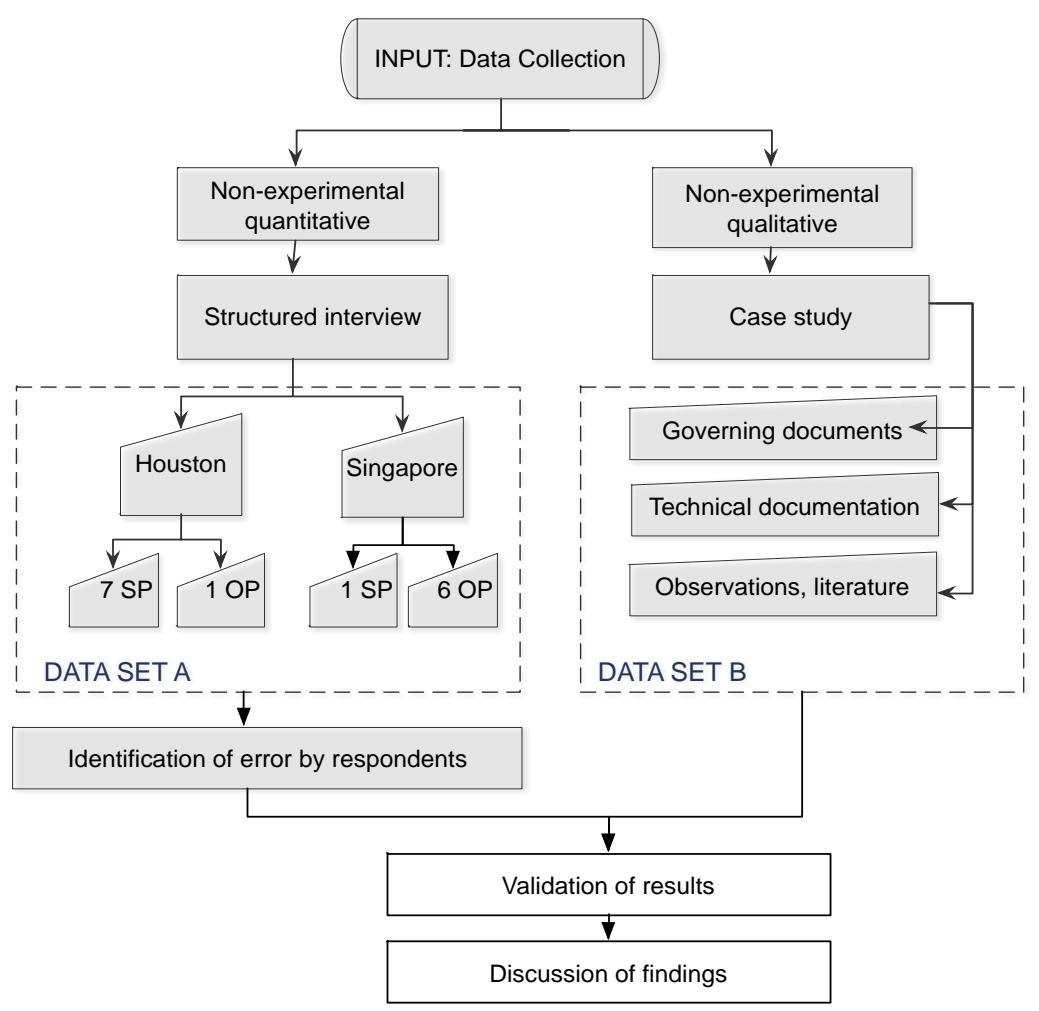

Figure 3. Data gathering and analysis process

These registers are highly vital, mainly related to safety uses such as to identify risks in the facility. The respondents argued that costs are kept to the minimum to increase the margin, especially in the case where respondents are not the asset owners. Vice versa, organizations that rent out their asset, without operating it themselves, are concerned about integrity of their asset.

\section{- Information management}

The integration of operating systems that are employed in the operation and maintenance phases presents another challenge. Respondents expressed their concerns regarding operating systems that are not interconnected with one another; thus, much information is missing and systems may not support each other (Kusumawardhani and Markeset, 2014). To avoid this problem, it is necessary to integrate the information systems and construct a solid structure that overlays the connection between operating systems. In such a case, a reliable database and information system would provide a great support to integrity management.

\section{- Data transfer between onshore and offshore}

Offshore installations are often located far from shore and lack the surrounding infrastructure. This causes difficulties in maintaining a communication line. One of the respondents suggested a solution through the installation of fiber optics. For long-distance offshore installations, fiber optics is an ideal technical solution since they have low line losses. Moreover, fiber optics is non-electrical, which makes them immune to electromagnetic interference (Tennyson et al., 2005). However, the cost of using fiber optics may be prohibitive over other traditional cables.

\section{- Information technology (IT) processes and security}

Smart technology is enabled by the combination of several advanced technologies (Khan et al., 2012, Torstensen and Skramstad, 2008). The basic model involves the input of data, analysis or processing of data that produces the outcome in a form of beneficial information, and lastly the distribution of information to the intended user, as illustrated in Figure 4.

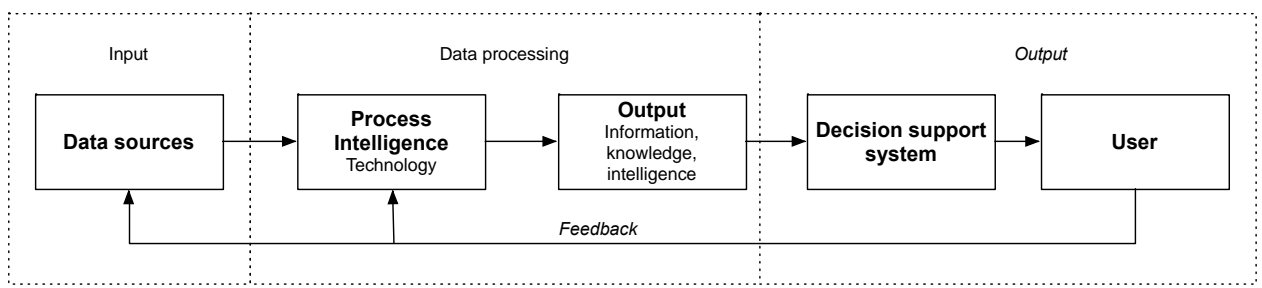

Figure 4. Basic model for data utilization 
The methods for processing data vary according to the facility requirements and their capabilities. Various information technology suppliers offer different custom-made solutions in the form of software and hardware or even system architecture, which allows the customer to tweak between business needs as well as the cost (see for example: Edison, 2011, Edwards et al., 2010).

Besides IT processes, the petroleum industry also frequently faces security threats to the company's information system and data, particularly within smart technology that utilizes networks as data transfer throughout the company and with external users. Aarset and Mo (2008) suggested a set of actions including planning and establishing a secure plant network, as well as implementing remote services. The separation of data that can be accessed by external users such as service suppliers is also crucial. Several technologies, such as fiber optic networks or data architecture, are able to mitigate this challenge (Forster and Dria, 2013, Tennyson et al., 2005).

\section{- Quality of data}

The availability of good quality and reliable data is one of the major issues in the petroleum industry (Griffiths, 2012, Ouertani et al., 2008). Despite being advantageous, previous experience has also revealed that data quality could be potentially beneficial or misleading (Radhay, 2008). The issues arise mainly because the quality of analysis depends greatly on the reliability and robustness of the initial data input, as illustrated in Figure 3.

Above all, in this automation era, the role of data is highly regarded due to the use of data as an input process. Besides data, other technology features, such as reliable sensors and other instruments are important for data quality, particularly in an environment with challenging operating conditions (Saunders, 2008). In addition to this, other factors such as governing documents, human factors, equipment and tools could also affect the quality of data (Kusumawardhani, 2013).

\section{- Integrated system}

Data integration and collaboration between involved parties has also become one of the challenges in delivering seamless information. Data integration involves the interaction around man, technology and organizations. Ringstad and Andersen (2006) have discussed similar challenges from the safety point of view. Sätra et al. (2011) have also suggested that collaboration needs to be further developed between organizations. One of the possible solutions is to manage the installation holistically, i.e. as a total system rather than as a set of isolated parts, during the entire lifecycle.

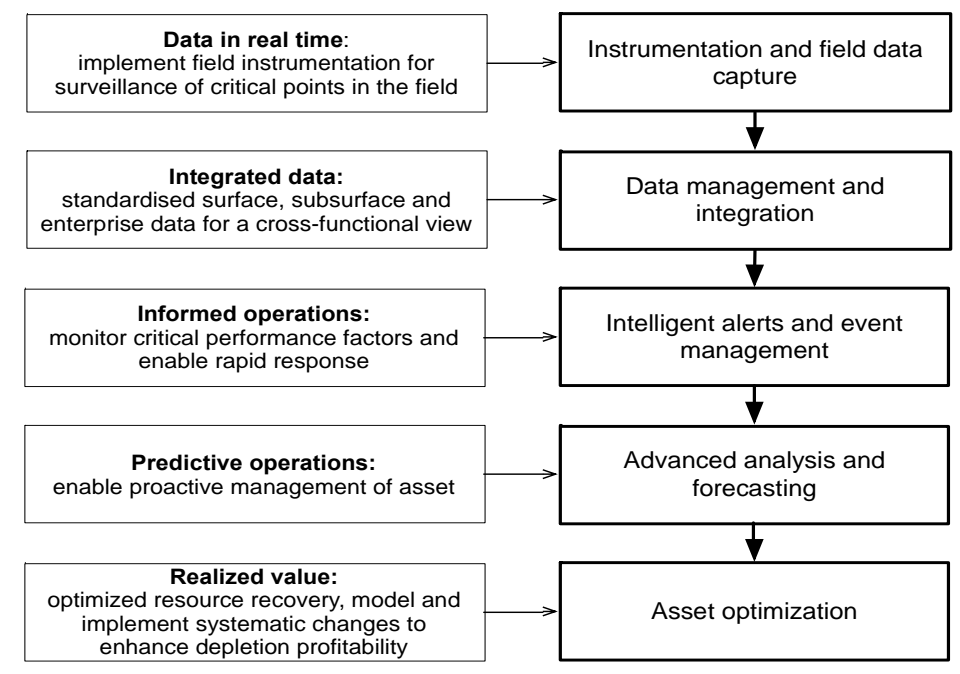

Figure 5. Towards smarter oil and gas fields (Edwards et al., 2010)

In order to achieve this, the organization needs to have a control system integrated with different departments and decision-makers to have the coordination to support the overall organization objective (El-Akruti and Dwight, 2013). Some service providers are already offering a holistic solution that focuses on the management and distribution of data, as illustrated in Figure 5. Therefore the data management for operation and maintenance is also part of holistic data management and should be built in such a way that it is integrated with the overall facility data management.

\section{INDUSTRIAL SERVICES AS A POSSIBLE SOLUTION}

Industrial services emerged as one possible solution following the increasing service market in the petroleum industry. The trend of outsourcing maintenance support services, alongside other segments such as subsea services and engineering services, has been increasingly popular in the last couple of decades. In maintenance services, inspection and maintenance alone has tripled its market value in the last two decades (Rystad-Energy, 2013).

To date, there is no commonly agreed definition of industrial service. However, for the purpose of this paper, 
industrial service will be defined as "processes and resources provided by a service company to a customer to produce performance that is meant to create output to provide solutions to the customer's needs" (Kusumawardhani and Markeset, 2014).

\subsection{Industrial Services for Petroleum Installations}

Following the fast-growing industrial development in the oil and gas industry, various service offerings exist in today's market. The main contributors to the development of service offerings are technology and knowledge. Both are present throughout the installation's lifecycle, as illustrated in Figure 6. The services are present in three different forms: customer service, service as value-added service, and service as the product (Bitner et al., 2000).

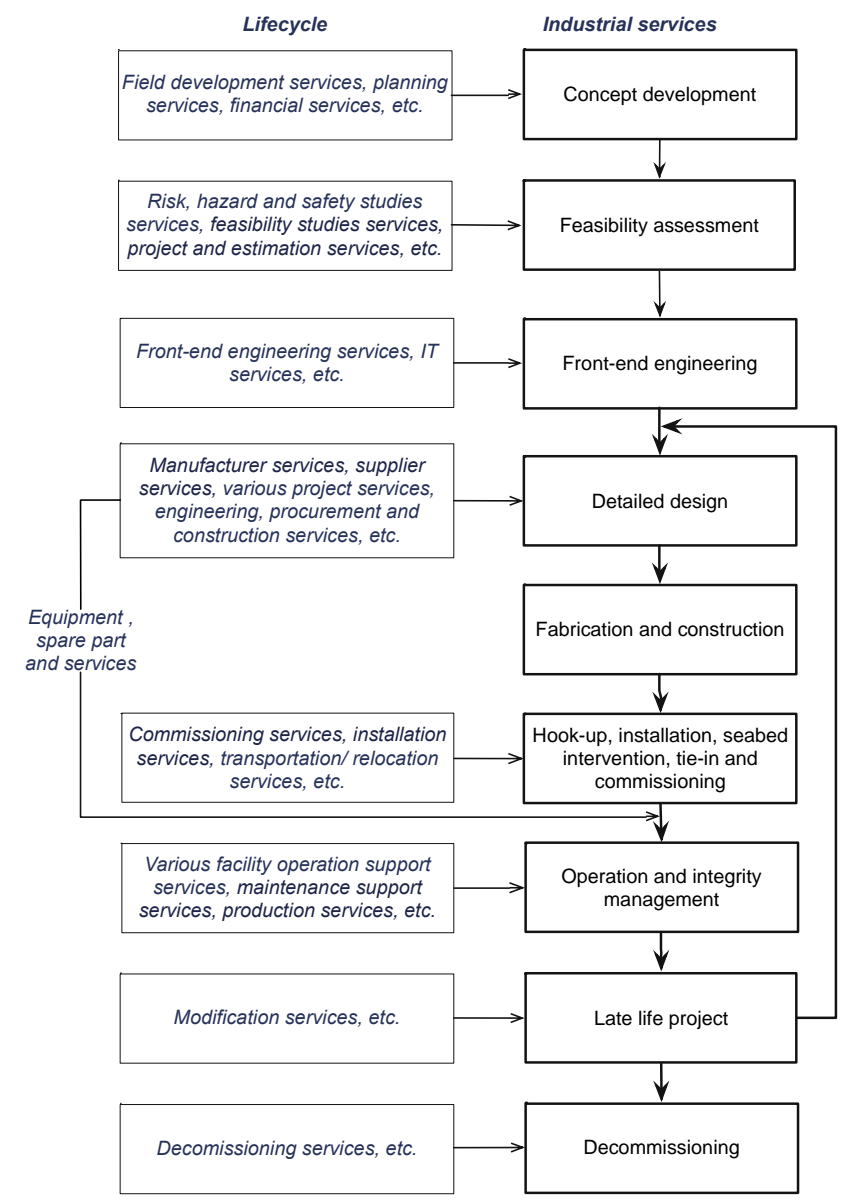

Figure 6. Industrial services in the lifecycle of a petroleum installation

The developments of technology and knowledge have both affected the way a company sells its service and physical products. In particular, companies have more advanced alternatives to merely offering conventional products, such as functional-product (Markeset and Kumar, 2005) or integrated product-service offerings (Park et al., 2012).
Technology has also been a big stimulator for the growth of service business. Technology exists as an enabler, mediator, and facilitator for the provision of physical products, service products or the integration of both. From the standpoint of service, technology has been seen as the instrument to provide new forms of business such as customization of service, new processes or new types of service encounters (Bitner et al., 2000). Services that exist because of technology are categorized as technologyenabled services. Meanwhile, from the standpoint of the product, technology is mainly seen as an instrument for new product development or to enhance existing ones (Ulrich, 2012).

The second contributor, knowledge, implies the filtering and interpretation of information to enable the user to act more effectively (Davis and Botkin, 1994). In practice, knowledge-based service involves the extraction of particular information from the source of knowledge that is relevant for the user, allowing the user to apply informed decision-making. Examples of knowledge-based services are financial consulting, engineering services, information technology (IT) services, etc.

\subsection{Industrial Service for KM Challenges}

Operators who have experienced the benefit of outsourcing have fostered a co-dependent relationship with service providers over the years. This is because, besides providing a solution, the engagement of service providers could give other benefits such as work efficiency, cost saving, distribution of risk, ability to be competitive, focus on core competences, technology innovation and adaptation, custom-made solutions, business transformation or expansion, and increased safety, availability, reliability and responsiveness (Jain and Natarajan, 2011, Sanjay and Ravi, 2007).

Particularly for KM, globalization has increased the availability and cost saving; for example, many advanced countries outsource their IT services to cheaper service providers in developing countries. Some of the benefits and potential solutions from engaging service providers for the challenges discussed in Section 2 are summarized in Table 2.

Conversely, the engagement of service providers is not without its own challenges. Organizations are often faced with several difficulties starting from the selection of service providers, managing the interface, quality issues, performance issues; even contractual issues (see for example Salonen, 2004, Arpan Kumar, 2014). Nevertheless, these challenges can be coped with through the organization's supplier management. There are several literature references that discuss risk, quality and performance issues (see for example Vilko and Ritala, 2014, Zakaria et al., 2010), contractual issues (see for example Stremersch et al., 2001, Panesar and Markeset, 2008) and supplier selection issues (see for example: Keramydas, 2011, McIvor, 2008). 
Table 2. Industrial service possible solutions for KM challenges

\begin{tabular}{|c|c|c|c|}
\hline KM challenges & Possible solutions & Industrial service providers & Potential benefits \\
\hline Knowledge transfer & $\begin{array}{l}\text { Establish procedure for knowledge transfer, } \\
\text { establish a shared network to exchange } \\
\text { information, establish lessons learned registers. }\end{array}$ & $\begin{array}{l}\text { Data architecture services, } \\
\text { network services, etc. }\end{array}$ & $\begin{array}{l}\text { Custom-made solutions, increased } \\
\text { mobility, increased reliability, etc. }\end{array}$ \\
\hline Information management & $\begin{array}{l}\text { Integration between operating systems, software } \\
\text { and various geographical locations. }\end{array}$ & $\begin{array}{l}\text { Data architecture services, } \\
\text { software services, etc. }\end{array}$ & $\begin{array}{l}\text { Integrated solutions, increased } \\
\text { availability, increased reliability, etc. }\end{array}$ \\
\hline $\begin{array}{l}\text { Data transfer between } \\
\text { onshore and offshore }\end{array}$ & $\begin{array}{l}\text { Establish tailor-made technology and network } \\
\text { solutions. }\end{array}$ & $\begin{array}{l}\text { Data architecture services, } \\
\text { fiber optic services, etc. }\end{array}$ & $\begin{array}{l}\text { Custom-made solutions, increased } \\
\text { security, increased reliability, etc. }\end{array}$ \\
\hline $\begin{array}{l}\text { Information technology } \\
\text { (IT) processes and } \\
\text { security }\end{array}$ & $\begin{array}{l}\text { Application of custom-made information } \\
\text { technology, network and architecture according } \\
\text { to requirements and regulations. }\end{array}$ & $\begin{array}{l}\text { Data architecture services, } \\
\text { fiber optic services, IT } \\
\text { security services, etc. }\end{array}$ & $\begin{array}{l}\text { Custom-made solutions, increased } \\
\text { security, increased reliability, core } \\
\text { competences focus, etc. }\end{array}$ \\
\hline Quality of data & $\begin{array}{l}\text { Ensure reliable data for input and processing into } \\
\text { information from the beginning of field } \\
\text { development through decommissioning. }\end{array}$ & $\begin{array}{l}\text { Engineering services, } \\
\text { information system services, } \\
\text { operation readiness services, } \\
\text { asset management services, } \\
\text { etc. }\end{array}$ & $\begin{array}{l}\text { Cost saving, competitive abilities, } \\
\text { increased reliability, etc. }\end{array}$ \\
\hline Integrated system & $\begin{array}{l}\text { Establish a control system integrated with } \\
\text { different departments and decision-makers to } \\
\text { have coordination to support the overall } \\
\text { organization objective. }\end{array}$ & $\begin{array}{l}\text { Asset management services, } \\
\text { IT services, engineering } \\
\text { services, etc. }\end{array}$ & $\begin{array}{l}\text { Increased safety, custom-made } \\
\text { solutions, increased } \\
\text { responsiveness, technology } \\
\text { adaptation, etc. }\end{array}$ \\
\hline $\begin{array}{l}\text { Introducing and adapting } \\
\text { to new technology }\end{array}$ & $\begin{array}{l}\text { Organization may opt to outsource new } \\
\text { technology requirement to service providers; that } \\
\text { way risk is distributed and organization is } \\
\text { avoiding high initial investment. }\end{array}$ & $\begin{array}{l}\text { Engineering services, } \\
\text { equipment manufacturer and } \\
\text { services, field services, etc. }\end{array}$ & $\begin{array}{l}\text { Cost saving, competitive abilities, } \\
\text { technology adaptation, etc. }\end{array}$ \\
\hline
\end{tabular}

\section{CONCLUDING REMARKS}

The extensive discussion of KM in the integrity of petroleum installations has revealed the challenges that are present as well as the known benefits. The engagement of industrial services could be of potential benefit to customers, mainly in outsourcing activities and saving the initial investment cost on technologies.

One of the challenges presented was the utilization of data and the integration of technology, to which some industrial service providers are offering solutions. However, integration does not stop at the level of technology; integration at organizational level is also one of the highlighted issues. Organizations need to actively participate in strategic technological collaborations amongst concerned parties for economic and security reasons. This having being said, the involvement of the customer in the outsourcing process and integration of activities is crucial for the overall integrity of petroleum installations.

From the interviews, it was also revealed that government regulations are often altered in favor of new technological advances. Customers who outsource to industrial services benefit from this situation, since the service provider who needs to deliver services that comply with the new regulations. By outsourcing to industrial services, the customer will be able to compete with the fastgrowing technology and their competitors without having to invest in buying new technologies.

\section{REFERENCES}

Aarset, M. F. \& Mo, O. (2008), It Security and Architecture for Integrated Operations: Examples from Deliveries to Ormen
Lange and Draugen. Intelligent Energy Conference and Exhibition. Amsterdam, The Netherlands: Society of Petroleum Engineers.

Arpan Kumar, K. (2014), Revisiting the Supplier Selection Problem: An Integrated Approach for Group Decision Support. Expert Systems with Applications, 41, pp. 2762 2771.

Bitner, M., Brown, S. \& Meuter, M. (2000), Technology Infusion in Service Encounters. Journal of the Academy of Marketing Science, 28, pp. 138-149.

Brule, M. (2013), Big Data in Exploration and Production: RealTime Adaptive Analytics and Data-Flow Architecture. 2013 SPE Digital Energy Conference and Exhibition. The Woodlands, TX, USA: Society of Petroleum Engineers.

Brynjolfsson, E. M. A. (2012), Race against the Machine : How the Digital Revolution Is Accelerating Innovation, Driving Productivity, and Irreversibly Transforming Employment and the Economy, Lexington, Mass., Digital Frontier Press.

Davis, S. \& Botkin, J. (1994), The Coming of Knowledge-Based Business. Harvard Business Review, 72, pp. 165-170.

Edison, L. S. (2011), The Value of Smarter Oil and Gas Fields. In: Insights, I. C. F. A. (ed.) http://www.ibm.com/. New York, USA: IBM.

Edwards, S., Ishaq, O. \& Johnsen, Ø. (2010), Oil and Gas 2030: Meeting the Growing Demands for Energy in the Coming Decades. In: Services, I. G. (ed.) http://www.ibm.com/. New York, USA: IBM.

El-Akruti, K. \& Dwight, R. (2013), A Framework for the Engineering Asset Management System. Journal of Quality in Maintenance Engineering, 19, pp. 398-412.

Fidler, E. S. (2009), Asset Performance Management Helps Oil and Gas Companies Increase Asset Availability, Improve Uptime and Empower More Intelligent Decision Making. 2009 Offshore Technology Conference : Proceedings; 4 - 7 May, Reliant Park, Houston, Texas, U.S.A. Richardson, Tex.: Offshore Technology Conference. 
Gang, N., Bo-Suk, Y. \& Michael, P. (2010), Development of an Optimized Condition-Based Maintenance System by Data Fusion and Reliability-Centered Maintenance. Reliability Engineering \& System Safety, 95, pp. 786 - 796.

Griffiths, P. (2012), Information Audit: Towards Common Standards and Methodology. Business Information Review, 29 , pp. 39-51.

Jain, R. K. \& Natarajan, R. (2011), Factors Influencing the Outsourcing Decisions: A Study of the Banking Sector in India. Strategic Outsourcing: An International Journal, 4, pp. 294-322.

Karim, R., Söderholm, P. \& Candell, O. (2009), Development of Ict-Based Maintenance Support Services. Journal of Quality in Maintenance Engineering, 15, pp. 127-150.

Khan, F., Testard, B., Boero-Rollo, J.-G. \& Verbrugge, E. (2012), Managing Operation Events in Real-Time: From Smart to Smarter. SPE Intelligent Energy International. Utrecht, The Netherlands: Society of Petroleum Engineers.

Keramydas, C., Xanthopoulos, A. \& Aidonis, D. (2011), A Decision-Making Framework for the Optimal Selection of Suppliers. Operations and Supply Chain Management, 4 (2/3), pp. 68 - 77.

Kusumawardhani, M. (2013), Reliability Analysis of NonDestructive Testing of Topside Flowline Pipe System on Aging Platform: Plant, Human and Technology. Master of Science Case Study, University of Stavanger.

Kusumawardhani, M. \& Markeset, T. (2014), Research Design for Industrial Service Studies. $6^{\text {th }}$ International Conference on Operations and Supply Chain Management (OSCM). Bali, Indonesia.

Kusumawardhani, M. \& Markeset, T. (2014), Asset Integrity of Deepwater Petroleum Production Facilities. In: Ieee, ed. IEEE International Conference on Industrial Engineering and Engineering Management (IEEM2014), December 09-12th 2014 Kuala Lumpur, Malaysia.

Marakas, G. M. \& O'brien, J. A. (2013), Introduction to Information Systems, New York, NY, McGraw-Hill/Irwin.

Markeset, T. \& Kumar, U. (2005), Product Support Strategy: Conventional Versus Functional Products. Journal of Quality in Maintenance Engineering, 11, pp. 53-67.

Mcivor, R. (2008), What Is the Right Outsourcing Strategy for Your Process? European Management Journal, 26, pp. 2434.

Ouertani, M.-Z., Parlikad, A. K. \& Mcfarlane, D. Asset Information Management: Research Challenges. Research Challenges in Information Science, 2008. RCIS 2008. Second International Conference on, 2008. IEEE, 361-370.

Panesar, S. S. \& Markeset, T. (2008), Industrial Service Innovation through Improved Contractual Relationship: A Case Study in Maintenance. Journal of Quality in Maintenance Engineering, 14, pp. 290-305.
Park, Y., Geum, Y. \& Lee, H. (2012), Toward Integration of Products and Services: Taxonomy and Typology. Journal of Engineering and Technology Management, 29, pp. 528-545.

Radhay, R. (2008), Facilitating Data Quality Improvement in the Oil and Gas Sector. SPE Asia Pacific Oil and Gas Conference and Exhibition. Perth, Australia: Society of Petroleum Engineers.

Ringstad, A. J. \& Andersen, K. (2006), Integrated Operations and Hse - Major Issues and Strategies. SPE International Health, Safety \& Environment Conference. Abu Dhabi, UAE: Society of Petroleum Engineers.

Rystad-Energy. (2013), Introduction to Rystad Energy's Offshore Market Report Norway. 2013 ed. Oslo, Norway: Rystad Energy.

Salonen, A. (2004), Managing Outsourced Support Services: Observations from Case Study. Facilities, 22, pp. 317-322.

Sanjay, J. \& Ravi, S. (2007), Selection of Logistics Service Provider: An Analytic Network Process (Anp) Approach. Omega, 35, pp. $274-289$.

Sätra, U. S. A., Christensen, R., Tanase, A., Koppervik, I. \& Rokke, E. 2011. Proactive Maintenance in the Context of Integrated Operations Generation 2. SPE Economics \& Management, 3, pp. 102-108.

Saunders, C. (2008), Thrulife - Integrity Management of Deepwater Subsea Systems [Online]. Woodgroup. Available: http://www.woodgroup.com/SiteCollectionDocuments/newstech-articles/2008-11_ThrulifeIM-Offshore_MCS.pdf [Accessed 05 December 2013].

Stremersch, S., Wuyts, S. \& Frambach, R. (2001), The Purchasing of Full-Service Contracts: An Exploratory Study within the Industrial Maintenance Market. Industrial Marketing Management, 30, pp. 1-12.

Tennyson, R. C., Don, W. \& Cherpillod, T. (2005), Monitoring Pipeline Integrity Using Fiber Optic Sensors. NACE International.

Torstensen, A. \& Skramstad, T. (2008), Reliable It for Integrated Operations. Intelligent Energy Conference and Exhibition. Amsterdam, The Netherlands: Society of Petroleum Engineers.

Ulrich, K. T. E. S. D. (2012), Product Design and Development, New York, McGraw-Hill/Irwin.

Vilko, J. \& Ritala, P. (2014), Service Supply Chain Risk Management. Operations and Supply Chain Management, 7(3), pp. 114 - 120.

Zakaria, H., Zailani, S. \& Fernando, Y. (2010), Moderating Role of Logistics Information Technology on the Logistics Relationships and Logistics Service Quality. Operations and Supply Chain Management, 3(3), pp. 134 - 147.

Mayang Kusumawardhani is a Research Fellow in the Department of Mechanical and Structural Engineering and Materials Science at the University of Stavanger, Norway. She holds a BEng degree in Mechanical Engineering and an MSc degree in Offshore Technology from the University of Stavanger. With nearly 10 years' experience in working in the petroleum industry within operation and maintenance engineering, she is currently pursuing a PhD degree in Offshore Technology, specializing in industrial asset management at the University of Stavanger.

Professor Tore Markeset is the Head of Department of Industrial Economics, Risk Management and Planning and Professor of Mechanical Engineering (Operations and Maintenance) at the University of Stavanger (UiS). He is Adjunct Professor at the University of Troms $\varnothing$, Norway. He was awarded a BSc degree in Petroleum Engineering from the University of Stavanger in 1985, BSc (1989) and MSc (1991) degrees in Mechanical Engineering from the University of Minnesota, USA, and a Dr. Ing. degree in Offshore Technology - Operations and Maintenance, at the UiS, in 2003, after working in the industry for a number of years. He has supervised $11 \mathrm{PhD}, 90 \mathrm{MSc}$ and $3 \mathrm{BSc}$ theses, as well as having published more than 130 papers. His research interests are in operation and maintenance engineering and management as well as industrial services. 